\title{
Proper Name Retrieval in Written Face Naming: Exploration with the Interference Paradigm
}

\author{
M. Izaute and P. Bonin
}

\section{(2) OpenEdition \\ 1 Journals}

Electronic version

URL: http://journals.openedition.org/cpl/201

DOI: $10.4000 / \mathrm{cpl} .201$

ISSN: $1379-6100$

Publisher

Centre PsyCLÉ

Printed version

Date of publication: 1 December 2001

\section{Electronic reference}

M. Izaute and P. Bonin, «Proper Name Retrieval in Written Face Naming: Exploration with the Interference Paradigm », Current psychology letters [Online], 2001/3, 6| 2001, Online since 05 September 2003, connection on 08 September 2020. URL : http://journals.openedition.org/cpl/201 ; DOI : https://doi.org/10.4000/cpl.201

This text was automatically generated on 8 September 2020.

(C) All rights reserved 
Proper Name Retrieval in Written Face Naming: Exploration with the Interference Paradigm

M. Izaute and P. Bonin 